УДК 619.9-092.9:616-08-031.084

(C) 2012

Улько Л. Г., кандидат ветеринарних наук

Сумський національний аграрний університет

\title{
ВИВЧЕННЯ ЕМБРІОТОКСИЧНОЇ Й ТЕРАТОГЕННОЇ ДІЇ ОКСИПРОЛУ
}

\section{Рецензент - доктор ветеринарних наук, професор А. В. Березовський}

Наведені дані з вивчення ембріотоксичних і тератогенних властивостей препарату «Оксипрол». Встановлено, щзо внутрішньом'язове введення препарату «Оксипрол» самкам щурів у дозі 0,1 мл/кг на 1-6-й, 6-16-й та 16-20-й дні вагітності не чинить ембріотоксичної й тератогенної дії на ембріони. Суттєвої різниці між плодовитістю самок

дослідних і контрольних груп не встановлено.

Середня кількість плодів на самку в дослідних $i$ контрольних групах знаходилося в межах 9, 1-9,6.

Щурята, отримані від піддослідних самок, були життєздатні й не відставали в рості та розвитку від контрольних.

Ключові слова: оксипрол, щури, тератогенні та ембріотоксичні властивості.

Постановка проблеми. Серед захворювань великої рогатої худоби найбільш розповсюдженими залишаються мастити, гнійно-некротичні ураження дистального відділу кінцівок і метрити. Вони завдають значих економічних збитків виробникам молока, котрі формуються за рахунок недоотримання i значного зниження його якості, передчасної вибраковки корів і затрат на лікування $[4,6,9]$.

Особливістю захворювань дистального відділу кінцівок у корів, які перебігають з ознаками гнійно-некротичного запалення, в сучасних умовах $€$ змішаний характер інфекції, у розвитку якої беруть участь представники різних груп мікроорганізмів [3, 7, 8, 10, 11]. Активізація умовно-патогенної мікрофлори відбувається на фоні порушення еволюційно сформованого симбіозу макроорганізму з власною аутофлорою під впливом численних зовнішніх чинників. В асоціації двох і більше збудників можливі різні типи взаємин (комплементації, незалежне одне від одного розмноження, інтерференція, екзальтація, тощо), котрі багато в чому визначають результат перебігу хвороби, ефективність проведеного лікування і варіюють залежано як від біологічних властивостей збудників, так і імунного статусу тварин [3].

Діагностика змішаних інфекцій вимагає проведення багатопланових лабораторних досліджень, а антибактеріальна терапія грунтується на чутливості мікроорганізмів, що входять в асоціацію, до антибактеріальних препаратів.

Аналіз основних досліджень і публікацій, у яких започатковано розв'язання проблеми. Останніми роками окремими проведеними експериментами 3'ясовано, що етіопатогенез гнійно-некротичних захворювань дистального відділу кінцівок має складний і багатокомпонентний характер, а в їньому виникненні основну роль відіграє бактеріальна мікрофлора $[8,10]$.

Незважаючи на значну кількість препаратів i схем лікування, запропонованих для терапії зазначених захворювань, проблема досі залишається невирішеною. Тому ветеринарна практика потребує ефективних препаратів для профілактики й лікування асоціативних бактеріозів великої рогатої худоби.

У ТОВ «Бровафарма ${ }^{\circledR}$ » (Україна) завершено розробку та реєстрацію антибактеріального препарату пролонгованої дії «Оксипрол», активно діючою речовиною якого є оксітетрациклін дигідрат. Препарат забезпечує універсально широкий спектр дії відносно збудників основних господарськи значимих бактеріозів, зокрема, маститу, метриту та гнійно-некротичних захворювань дистального відділу кінцівок, викликаних асоціацією умовно-патогенних мікроорганізмів (Escherichia coli. Staphylococcus aureus, Staphylococcus epidermidis, Staphylococcus saprophiticus, Enterococcus faecalis, Streptococcus pyogenes, Streptococcus agalactiae, Klebsiella pneumoniae, Proteus vulgaris, Pseudomonas aeruginosa, Clostridium septicum, Clostridium perfringens, Clostridium oedematiens, Dichelobacter nodosus, Fusobacterium necrophorum).

Дослідження ембріотоксичної і тератогенної дії препарату дають змогу встановити характер і вираженість його шкідливої дії на організм плодів експериментальних тварин залежно від терміну внутрішньоутробного розвитку, оцінити безпечність його застосування при вагітності.

Мета досліджень та методика їх проведення. Метою дослідження було виявити можливі ембріотоксичні й тератогенні властивості препарату «Оксипрол». 
Вивчення можливих ембріотоксичних і тератогенних властивостей препарату «Оксипрол» проводили за загальноприйнятими методами $[1,2,5]$. Експерименти проведені на 120 безпородних білих щурах-самках масою 180-240 г, які утримувалися в оптимальних умовах віварію (iз забезпеченням температурного, світлового режиму, повноцінного харчування, захисту від інфекцій, шуму та ін. несприятливих факторів навколишнього середовища). У роботі з експериментальними тваринами керувалися «Свропейською конвенцією із захисту хребетних тварин». У процесі вибору тварин для досліду у самиць проводили дослідження естрального циклу. Перший день вагітності встановлювали за наявністю сперматозоїдів у мазках самиць.

Дослідження ембріотоксичної дії препарату «Оксипрол» проводили в терапевтичній дозі 0,1 мл/кг. Препарат тваринам вводили внутрішньом'язово. Дозу тестованого препарату розраховували на одиницю маси тіла самки. Вагітні самиці були розподілені на чотири групи, по 20 тварин у групі. Щурам I дослідної групи препарат вводили 3 першої по шосту добу вагітності, II дослідної групи - (період передімплантаційного розвитку), з шостої по шістнадцяту (період плацентації і органогенезу), III дослідної групи - 3 шістнадцятої по двадцяту добу вагітності (плодовий період розвитку). Самицям IV, V, та VI груп, які служили інтактним контролем, в зазначені терміни внутрішньом'язово вводили фізіологічний розчин. Вагітних щурів утримували в окремих клітках, забезпечивши їх необхідною підстилкою для влаштування гнізда. 3 першого дня вагітності за тваринами встановлювали спостереження: контролювали стан і поведінку самок, реєстрували динаміку зміни маси тіла, тривалість вагітності, перебіг пологів. Паралельно вели спостереження за контрольними групами тварин.

Облік результатів експерименту проводили як при забої вагітних самок, на 20-й день вагітності, так і станом потомства в постнатальний період розвитку. Після евтаназії під легким ефірним наркозом тварин шляхом дислокації шийних хребців, робили розтин черевної порожнини та рогів матки, враховуючи наступні показники: кількість жовтих тіл вагітності, кількість живих плодів, кількість мертвих плодів, кількість місць резорбції, стан плаценти.

Плоди і плаценти зважували, вимірювали куприковотім'яну (краніо-каудальну) відстань, розраховували масоростовий коефіцієнт плодів i плодоплацентарний коефіцієнт. Резорбовані плоди, які загинули на ранніх стадіях розвитку, мають вигляд невеликих темних утворень (розмірами з крапку), на більш пізніх етапах - гомогенних тіл діаметром 2,5-3 мм і більше. Результати розтину вагітних самок реєстрували в протоколі.

Після лапаротомії у тварин виділяли роги матки 3 яєчниками. Переносили їх у чашку Петрі 3 фізіологічним розчином. За допомогою бінокулярної лупи проводили ретельний огляд яєчників, підраховували кількість жовтих тіл вагітності. Жовті тіла - це виноградоподібні просвіти в яєчниках жовтуватого або рожевого кольору. Число їх зазвичай буває рівним або дещо вищим, ніж число місць імплантацій.

На підставі даних експериментів визначали наступні параметри:

a) загальну ембріональну смертність (\%) $(\mathrm{B}-\mathrm{A})$ : B x 100;

б) доімплантаційну смертність ((\%) - [B - (А + Б): B] x 100;

в) постімплантаційну смертність (\%) - Б: (А + Б) $\mathrm{x} 100$,

де: А - кількість живих плодів;

Б - кількість мертвих і резорбованих ембріонів;

В - кількість жовтих тіл вагітності.

Показниками ембріотоксичної дії Оксипролу вважали:

а) ембріональну (до- та постімплантаційну) загибель плодів;

б) відставання у розвитку, що проявляється у зменшенні маси тіла і краніо-каудальних розмірів плодів;

в) поява патології розвитку внутрішніх органів;

г) поява зовнішніх аномалій (тератогенний ефект).

Тератогенний ефект речовини відзначали на початку візуально (у процесі розтину вагітних самок). Потім частина плодів (2/3 від загального числа плодів у досвіді) фіксували в $95 \%$ етиловому спирті для подальшої оцінки стану кісткової системи на просвітлених речовинах, пофарбованих алізарин за методом Даусона. Решту плодів опускали в рідину Бауен для мікроанатомічного аналізу за методом Вільсона.

Новонароджених щурят оглядали, реєстрували краніо-каудальний розмір, визначали масу тіла. Враховували випадки загибелі щурят від моменту народження до припинення вигодовування.

Вивчаючи постнатальний розвиток потомства від дослідних і контрольних щурів, врахували 
наступні показники: динаміку збільшення маси тіла, час відкривання очей, відлипання вушної раковини, появу первинного і постійного шерстного покриву, прорізування різців, індекс життездатності (число живих новонароджених / число народжених), індекс лактації (число живих щурят до 21-го дня життя / число живих щурят до 4-го дня життя), індекс виживання (число щурят, які вижили до 4-го дня / число народжених живими). На 30-у добу після народження щурят умертвляли за допомогою дислокації шийних хребців і проводили гістологічне дослідження внутрішніх органів.

Статистичну обробку результатів проводили методами математичної статистики із застосуванням пакетів прикладних програм «Біостатистика для Windows, версія 4.03» та «Microsoft Excel 2002». Для кожного досліджуваного показника визначали середне арифметичне (M) і стандартну похибку середнього арифметичного (m). Достовірними вважали відмінності з рівнем значимості понад $95 \%(\mathrm{p}<0,05)$.

Результати досліджень. У ході проведення макроскопічного огляду плодів самок, які отримували Оксипрол у різні строки вагітності, вияв- лено, що в усіх ембріонів дослідних і контрольних груп були відсутні вади лицевого та мозкового черепу. Сам череп мав овально-довгасту форму. Вушна раковина та повіки очей були закриті. Передня черевна стінка зарощена, без ознак пупкової грижі. Хвіст був звичайної довжини. Кінцівки мали добре розвинуте плече, передпліччя, кість, стегно, гомілку та стопу. Положення, форма кінцівок, кількість пальців та їх розміри у ембріонів дослідних і контрольних перебували в межах норми. На шкірі були відсутні ознаки порушення пігментації.

Дослідженням показників ембріолетальної дії Оксипролу встановлено: показники вагітних самок дослідних груп відповідали аналогічним показникам контрольних щуриць. Показники передімплантаційної (доімплантаційної), післяімплантаційної та загальної ембріональної летальності в дослідних групах не мали вірогідних відмінностей від показників у контролі. У дослідних тварин маса плодів та їх краніо-каудальний розмір, маса плацент та їх діаметр не мали достовірних відмінностей від показників контрольних тварин. Зовнішніх вад розвитку не було. Співвідношення статей в посліді не зазнало змін.

1. Результати вивчення ембріонального матеріалу, отриманого від самок иурів після введення Оксипролу

\begin{tabular}{|c|c|c|c|c|c|c|}
\hline \multirow{2}{*}{ Показник } & \multicolumn{3}{|c|}{ Дослід } & \multicolumn{3}{c|}{ Контроль } \\
\cline { 2 - 7 } & \multicolumn{1}{|c}{ група тварин / дні введення препарату } & \multicolumn{2}{|c|}{ група тварин / дні введення препарату } \\
\cline { 2 - 7 } & $\mathrm{I} / 1-6$ & $\mathrm{II} / 6-16$ & \multicolumn{1}{|c|}{ III/16-20 } & IV/1-6 & V/6-16 & VI/16-20 \\
\hline $\begin{array}{c}\text { Кількість живих } \\
\text { плодів у посліді }\end{array}$ & $9,8 \pm 0,42$ & $9,6 \pm 0,34$ & $9,8 \pm 0,51$ & $9,7 \pm 0,37$ & $9,1 \pm 0,28$ & $9,5 \pm 0,40$ \\
\hline $\begin{array}{c}\text { Загальна ембріона- } \\
\text { льна смертність, \% }\end{array}$ & $9,94 \pm 0,45$ & $9,37 \pm 0,45$ & $9,24 \pm 0,61$ & $9,59 \pm 0,63$ & $9,64 \pm 0,29$ & $9,47 \pm 0,29$ \\
\hline $\begin{array}{c}\text { Доімплантаційна } \\
\text { смертність, од. }\end{array}$ & $10,74 \pm 0,37$ & $10,56 \pm 0,56$ & $10,07 \pm 0,58$ & $9,64 \pm 0,29$ & $9,82 \pm 0,48$ & $9,80 \pm 0,82$ \\
\hline $\begin{array}{c}\text { Постімплантаційна } \\
\text { смертність, од. }\end{array}$ & $9,14 \pm 0,48$ & $8,58 \pm 0,25$ & $8,01 \pm 0,32$ & $8,33 \pm 0,0$ & $9,32 \pm 0,23$ & $9,14 \pm 0,48$ \\
\hline Маса плода, г & $1,91 \pm 0,03$ & $1,89 \pm 0,02$ & $1,90 \pm 0,03$ & $1,88 \pm 0,03$ & $1,88 \pm 0,02$ & $1,89 \pm 0,02$ \\
\hline $\begin{array}{c}\text { Краніокаудальні } \\
\text { розміри, мм }\end{array}$ & $30,70 \pm 0,17$ & $30,65 \pm 0,25$ & $30,75 \pm 0,28$ & $30,90 \pm 0,22$ & $30,60 \pm 0,22$ & $30,65 \pm 0,24$ \\
\hline Маса плаценти, г & $0,41 \pm 0,02$ & $0,40 \pm 0,02$ & $0,42 \pm 0,02$ & $0,43 \pm 0,03$ & $0,40 \pm 0,03$ & $0,41 \pm 0,02$ \\
\hline $\begin{array}{c}\text { Діаметр плаценти, } \\
\text { мм }\end{array}$ & $13,4 \pm 0,26$ & $13,5 \pm 0,15$ & $13,46 \pm 0,18$ & $13,45+0,19$ & $13,40+0,16$ & $13,45+0,19$ \\
\hline $\begin{array}{c}\text { Зовнішні вади } \\
\text { розвитку, \% }\end{array}$ & 0 & 0 & 0 & 0 & 0 & 0 \\
\hline $\begin{array}{c}\text { Самців / самок } \\
\text { у посліді, \% }\end{array}$ & $54,17 / 45,83$ & $52,08 / 47,92$ & $51,06 / 46,94$ & $46,15 / 53,85$ & $53,85 / 46,15$ & $52,63 / 47,37$ \\
\hline
\end{tabular}


ВЕТЕРИНАРНА МЕДИЦИНА

\section{2. Результати морфоанатомічного дослідження внутрішніх органів ембріонів щурів після введення Оксипролу}

\begin{tabular}{|c|c|c|c|c|c|c|}
\hline \multirow{3}{*}{ Показник } & \multicolumn{3}{|c|}{ Дослід } & \multicolumn{3}{|c|}{ Контроль } \\
\hline & \multicolumn{3}{|c|}{$\begin{array}{c}\text { група тварин / дні введення } \\
\text { препарату }\end{array}$} & \multicolumn{3}{|c|}{$\begin{array}{c}\text { група тварин / дні введення } \\
\text { препарату }\end{array}$} \\
\hline & $\mathrm{I} / 1-6$ & $\mathrm{II} / 6-16$ & III/16-20 & IV/1-6 & $V / 6-16$ & $\mathrm{VI} / 16-20$ \\
\hline Кількість оглянутих ембріонів & 96 & 96 & 98 & 97 & 91 & 95 \\
\hline Переповнення судин кров’ю, од. / \% & $0 / 0$ & $0 / 0$ & $1 / 1,02$ & $0 / 0$ & $2 / 2,20$ & $1 / 1,05$ \\
\hline $\begin{array}{c}\text { збільшення розмірів сечового міхура, } \\
\text { од. / \% }\end{array}$ & $1 / 1,04$ & $2 / 2,08$ & $0 / 0$ & $1 / 1,03$ & $2 / 2,20$ & $0 / 0$ \\
\hline $\begin{array}{c}\text { Крововиливи у внутрішні органи, } \\
\text { од / \% }\end{array}$ & $1 / 1,04$ & $0 / 0$ & $0 / 0$ & $0 / 0$ & $0 / 0$ & $2 / 2,11$ \\
\hline Підшкірні гематоми, од. / \% & $0 / 0$ & $1 / 1,04$ & $0 / 0$ & $1 / 0,03$ & $0 / 0$ & $0 / 0$ \\
\hline $\begin{array}{c}\text { Розширення шлуночків } \\
\text { головного мозку, од. / \% } \\
\end{array}$ & $1 / 1,04$ & $0 / 0$ & $0 / 0$ & $0 / 0$ & $0 / 0$ & $0 / 0$ \\
\hline $\begin{array}{c}\text { Каліцтва, аномалії розвитку } \\
\text { внутрішніх органів та скелета }\end{array}$ & відсутні & відсутні & відсутні & відсутні & відсутні & від \\
\hline
\end{tabular}

На першому розрізі, який проводили перпендикулярно до нижньої щелепи, вивчали стан переднього відділу твердого піднебіння, нижньої щелепи, носової перегородки, хоан. У всіх переглянутих ембріонів нижня і верхня щелепи були без патологій, язик вільно містився у роті. Тверде піднебіння - без ознак розщеплення, носова перегородка не скривлена.

Другий розріз проводили через середину очних яблук і орбіт. Нюхові бульбочки розташовані в лобовій частині головного мозку, - великі, на розрізі мають довгасту овальну форму. Очні орбіти та яблука - парні, розташовані на одному рівні, без патології.

Третій розріз проводили через поперечний діаметр головного мозку (перед вухами), четвертий розріз - паралельно третьому, але за вухами. На цих розрізах розглядали стан головного мозку. У всіх ембріонів відділи головного мозку розвинуті пропорційно. На розрізах простежувалися півкулі, таламус (проміжний мозок), мозочок, бічні, третій і четвертий шлуночки головного мозку. Бічні шлуночки головного мозку мали вигляд вузької щілини. Третій шлуночок на розрізі був невеликий, краплеподібної форми. Четвертий шлуночок мав сплющену, наметоподібну форму. Субдуральний простір у всіх оглянутих плодів не перевищував межі норми. У двох та одного плода V та VI контрольних груп (2,20\% та $1,05 \%)$ і одного плода III дослідної групи $(1,02 \%)$ спостерігали наповнення кровоносних судин головного мозку кров'ю, а в одного ембріона I дослідної групи зафіксовано розширення шлуночка головного мозку. Підшкірні гематоми виявлені в одного 3 ембріонів II дослідної та I контрольної груп. Набряків підшкірної клітковини у плодів дослідних і контрольних груп виявлено не було.

П'ятий розріз проводили через гортань, стравохід, спинний мозок, великі кровоносні судини і слинні залози. Усі вищеперераховані утворення звичайної топографії, без видимої патології. Субарахноїдальний простір був у нормі, діаметр кровоносних судин приблизно однаковий у всіх ембріонів дослідних та контрольних груп.

Шостий розріз проводили над верхніми кінцівками. На ньому просліджували стан стравоходу, трахеї, кровоносних судин, спинного мозку. На цьому рівні розрізу видимої патології не виявлено. Стравохід на всьому протязі був вільний, без ознак стенозу, кільця трахеї - добре розвинуті, звичайної топографії. Сьомий розріз проводили під верхніми кінцівками. На розрізі були чітко проглядались органи грудної порожнини: чотирьохкамерне серце, правий і лівий шлуночки, праве і ліве вушко, права легеня (що складалася з чотирьох часток) і однодольна ліва легеня. Сама тканина легень мала добре виражену коміркову структуру, розвинуті бронхи. В порожнині перикарду у частини ембріонів як у дослідних групах, так і в контрольних групах, визначали наявність крові. На цьому ж розрізі переглядали також стан стравоходу і спинного мозку. Всі органи були звичайної топографії й розмірів.

Восьмий розріз проводили через печінку, яка складалася із шести часток, була звичайної консистенції і кольору. Після огляду печінки іï видаляли й оглядали діафрагму. Діафрагмова перегородка мала трохи ввігнуту форму, цільність їі 
не порушена. В одного з ембріонів I дослідної та III контрольної груп було виявлено крововиливи у внутрішні органи.

Дев'ятий розріз у частини ембріонів проводили нижче пупкового кільця, у частини розріз робили впродовж черевної порожнини і малого таза. Як на поперечних, так і на поздовжніх розрізах органи черевної порожнини були звичайної топографії, без ознак патології. Шлунок - великий, на розрізі ніжно складчастий. Підшлункова залоза - компактна, у ній добре помітні (повздовжній розріз) голова, тіло і хвіст.

Селезінка була звичайною, помірною за розміром. Видаливши переглянуті органи, оглядали сечостатеву систему. Нирки у всіх ембріонів були розташовані трохи асиметрично. На розрізі ниркова балія не мала ознак гідронефрозу. Досить великі наднирники були овальної форми. Сечоводи прямі на всьому протязі. Сечовий міхур мав малий розмір, однак у незначної частини плодів I та II дослідних і IV та V контрольних груп спостерігали збільшення розмірів сечового міхура. Пряма кишка - без видимої патології. У самців спостерігали чітко розвинуті парні тестикули 3 придатками, у самиць - дворогу матку й яєчники (розташовані за нирками).

Результати морфо-анатомічного дослідження внутрішніх органів ембріонів щурів, які у різні періоди вагітності отримували оксипрол у дозі
0,1 мл/кг, показали відсутність у 20-денних плодів вірогідних змін порівняно 3 контролем у стані внутрішніх органів та тканин.

При дослідженні кісткової системи ембріонів визначали характер осифікації черепу, кістяка, кінцівок, просторове розташування і форму кісток, кількість закладок у метакарпальних і метатарзальних кістках, кількість осифікацій у грудині, у тазовому поясі, у хребті. Дані морфоанатомічного дослідження кісткової системи ембріонів щурів, які отримували Оксипрол у різні строки вагітності, наведені у таблиці 3.

Дослідження закладок лицьового черепа плодів не виявило аномалій розвитку. У всіх ембріонів були добре розвинуті нижня та верхня щелепи, носові перегородки та очні орбіти. Кісткові закладки в лобовій, акуловій, гратчастій кісках ембріонів були добре помітні. Кісткова тканина мала яскраве забарвлення. У поодиноких ембріонів II і III дослідних груп та I і II контрольної груп виявлена відсутність верхньої частини потиличної кістки, проте виявлені відхилення не виходили за межі аналогічних показників контролю. В ембріонів як дослідних, так і контрольних груп спостерігали зменшення кісткових закладок у під'язиковій кістці. У ході дослідження хребта ембріонів також не виявлено вірогідних порушень осифікації у плодів дослідних

3. Показники осифікації кістяка плодів цурів, які отримували Оксипрол у дозі 0,1 мл/кг маси

\begin{tabular}{|c|c|c|c|c|c|c|c|}
\hline \multirow{3}{*}{\multicolumn{2}{|c|}{ Показник }} & \multicolumn{3}{|c|}{ Дослід } & \multicolumn{3}{|c|}{ Контроль } \\
\hline & & \multicolumn{3}{|c|}{ група тварин / дні введення препарату } & \multicolumn{3}{|c|}{ група тварин / дні введення препарату } \\
\hline & & $\mathrm{I} / 1-6$ & $\mathrm{II} / 6-16$ & $\mathrm{III} / 16-20$ & IV/1-6 & $\mathrm{V} / 6-16$ & $\mathrm{VI} / 16-20$ \\
\hline \multirow{2}{*}{ Лопатка } & ліва & $2,35 \pm 0,02$ & $2,38 \pm 0,01$ & $2,36 \pm 0,02$ & $2,37 \pm 0,02$ & $2,35 \pm 0,02$ & $2,37 \pm 0,02$ \\
\hline & права & $35 \pm 0,02$ & $2,38+0,01$ & $2,36 \pm 0,02$ & $2,36 \pm 0,02$ & $2,35 \pm 0,02$ & $2,37 \pm 0,02$ \\
\hline \multirow{2}{*}{ Плечова } & & $2,49 \pm 0,03$ & $2,48 \pm 0,02$ & 2 & $\overline{51 \pm 0}$ & $2,47 \pm 0,02$ &, 02 \\
\hline & права & $2,49+0$ & $2,49+$ & & 2,51 & 2,49 & 0,02 \\
\hline \multirow{2}{*}{ Ліктьова } & & & $2,62+$ & & & 2,60 & 0,02 \\
\hline & права & 2,6 & $2,63 \pm$ & & & $2,60=$ & 02 \\
\hline \multirow{2}{*}{ Променева } & ліва & 2,0 & $2,01=$ & 2,0 & 1 , & $2,00=$ & 03 \\
\hline & права & & 2,0 & & & & \\
\hline \multirow{2}{*}{ Стегнова } & & & 1,8 & & & 1,7 & \\
\hline & права & & 1,8 & & & 1,8 & \\
\hline \multirow{2}{*}{$\begin{array}{c}\text { Велика } \\
\text { гомілкова }\end{array}$} & ліва & & $2,06=$ & & 2,0 & 2,0 & \\
\hline & права & & $2,07 \pm$ & 2,0 & 2,0 & 2,08 & 01 \\
\hline \multirow{2}{*}{$\begin{array}{c}\text { Мала } \\
\text { гомілкова }\end{array}$} & ліва & $1,89 \pm 0,02$ & $1,89 \pm 0,02$ & & $1,83 \pm$ & $1,91 \pm 0,03$ & $1,86+0,03$ \\
\hline & права & $1,88 \pm 0,02$ & $1,89+0,02$ & $1,87 \pm 0,02$ & $1,84+0,02$ & $1,90 \pm 0,03$ & $1,86+0,02$ \\
\hline \multirow{2}{*}{$\begin{array}{c}\text { Нижня } \\
\text { щелепна }\end{array}$} & зліва & $7,06 \pm 0,02$ & $7,05 \pm 0,02$ & $\pm 0,01$ & $7,05 \pm 0,03$ & $7,05 \pm 0,03$ & $7,06 \pm 0,02$ \\
\hline & зправа & 2 & $7,05 \pm 0,02$ & & $7,05 \pm 0,03$ & $7,05 \pm 0,03$ & $\pm 0,02$ \\
\hline \multirow{2}{*}{ Тім'яна } & ліва & & $4,92 \pm$ & & & & \\
\hline & права & & & & & & \\
\hline \multicolumn{2}{|c|}{ Кількість хребців } & $30,1 \pm 0,10$ & $30,20 \pm 0,13$ & $30,0 \pm 0,21$ & $30,20 \pm 0,25$ & $29,80 \pm 0,20$ & $29,90 \pm 0,18$ \\
\hline
\end{tabular}


ВЕТЕРИНАРНА МЕДИЦИНА

\section{4. Показники постембріонального розвитку иурят, отриманих від самок, яким вводили препарат «Оксипрол»}

\begin{tabular}{|c|c|c|c|c|c|c|}
\hline \multirow{2}{*}{ Показник } & \multicolumn{5}{|c|}{ Дослід } & \multicolumn{3}{c|}{ Контроль } \\
\cline { 2 - 7 } & група тварин / дні введення препарату & \multicolumn{2}{|c|}{ група тварин / дні введення препарату } \\
\cline { 2 - 7 } & I/1-6 & II/6-16 & III/16-20 & IV/1-6 & V/6-16 & VI/16-20 \\
\hline $\begin{array}{c}\text { Середня кількість } \\
\text { плодів на самку, } \\
\text { гол. }\end{array}$ & $9,10 \pm 0,28$ & $9,20 \pm 0,25$ & $9,20 \pm 0,33$ & $9,60 \pm 0,31$ & $9,10 \pm 0,31$ & $9,30 \pm 0,26$ \\
\hline $\begin{array}{c}\text { Маса щурят } \\
\text { у 1-й день, г }\end{array}$ & $4,92 \pm 0,04$ & $4,87 \pm 0,04$ & $4,89 \pm 0,04$ & $4,93 \pm 0,06$ & $4,87 \pm 0,04$ & $4,95 \pm 0,05$ \\
\hline $\begin{array}{c}\text { Середньодобовий } \\
\text { приріст маси } \\
\text { щурят, г }\end{array}$ & $1,68 \pm 0,04$ & $1,73 \pm 0,05$ & $1,77 \pm 0,03$ & $1,70 \pm 0,05$ & $1,67 \pm 0,04$ & $1,72 \pm 0,04$ \\
\hline $\begin{array}{c}\text { Поява шерстного } \\
\text { покриву, діб }\end{array}$ & $5,20 \pm 0,13$ & $5,10 \pm 0,18$ & $5,20 \pm 0,20$ & $5,20 \pm 0,13$ & $5,10 \pm 0,10$ & $5,10 \pm 0,18$ \\
\hline $\begin{array}{c}\text { Відлипання вушної } \\
\text { раковини, діб }\end{array}$ & $13,10 \pm 0,10$ & $13,20 \pm 0,13$ & $13,20 \pm 0,13$ & $13,30 \pm 0,15$ & $13,30 \pm 0,15$ & $13,10 \pm 0,10$ \\
\hline $\begin{array}{c}\text { Відкривання очної } \\
\text { щілини, діб }\end{array}$ & $16,10 \pm 0,23$ & $16,0 \pm 0,26$ & $16,10 \pm 0,18$ & $16,10 \pm 0,10$ & $16,0 \pm 0,26$ & $16,10 \pm 0,18$ \\
\hline $\begin{array}{c}\text { Індекс } \\
\text { життєздатності }\end{array}$ & 1 & 1 & 1 & 1 & 1 & 1 \\
\hline Індекс виживання & 1 & 1 & 1 & 1 & 1 & 1 \\
\hline Індекс лактації & 1 & 1 & 1 & 1 & 1 & 1 \\
\hline
\end{tabular}

груп порівняно 3 плодами контрольних груп. Число пар ребер - 13. У шийному відділі осифіковані лише дуги хребців. У грудному, поперековому та крижовому відділах закладки осифікації знайдені як у дугах, так і в тілах хребців.

Процес осифікації відбувався синхронно. У деяких плодів дослідних і контрольних груп виявлено зниження кісткових закладок у дугах хребців поперекового відділу. У тазовому поясі плодів ядра осифікації були відзначені в трьох окремих кістках: клубовій, сідничній і лобковій. У ембріонів усіх груп вони були відокремлені одна від одної. Найбільш осифікованою була клубова кістка; у двох інших тазових кістках процес осифікації відбувався повільніше.

Дослідження кісток верхніх і нижніх кінцівок ембріонів не виявило аномалій в їхньому розвитку. Плечовий пояс був чітко осифікований. У ключиці осифіковано лише тіло. Кістки плеча,

\section{БІБЛІОГРАФІЯ}

1. Доклінічні дослідження ветеринарних лікарських засобів / За ред. І. Я. Коцюмбаса. - Львів : Тріада плюс, 2006. -360 с.

2. Доклінічні дослідження лікарських засобів (методичні рекомендації) / За редакцією О. В. Стефанова. - К. : Авіцена, 2001. - 138 с.

3. Идогов В. В. Динамика некоторых имунологиеских показателей у коров больных гнойным передпліччя, стегна і гомілки мали виражений характер осифікації діафізів і епіфізів.

Кістки черепа, крижові хребці, трубчасті кістки, ядра осифікації в дистальних відділах кінцівок сформовані й не відрізнялися за розміром від контрольних тварин.

Суттєвої різниці між плодовитістю щурів дослідних i контрольних груп не встановлено. Середня кількість плодів на самку в дослідних і контрольних групах перебувало в межах 9,1-9,6. Щурята, отримані від піддослідних самок, були життєздатні й не відставали в рості та розвитку від контрольних.

Висновок. Препарат «Оксипрол» за внутрішньом'язового введення в дозі 0,1 мл/кг на 1-6-й, 6-16-й та 16-20-й дні вагітності не чинить ембріотоксичної і тератогенної дії на ембріони щурів.

пододерматитом / В. В. Идогов, В. А. Ермолаев, Е. М. Марьин [и др.] / Материалы Междунар. научно-практ. конф. «Ветеринарная медицина XXI века: инновации, опыт, проблемы и пути их решения», посвящённой Всемирному году ветеринарии в ознаменование 250-летия профессии ветеринарного врача. - Ульяновск, 2011. - Т. 1. C. $129-130$. 
4. Козій В. I. Залежність рівня захворюваності у ділянці пальця від стану годівлі та рубцевого травлення у високопродуктивних корів / В. І. Козій, О. В. Чуб, В. В. Сахнюк // Вісник СНАУ. 2004. - Вип. 7 (12). - С. 77-78.

5. Методичні рекомендації по експериментальному вивченню ембріотоксичної дії лікарських засобів. - К., 2000. -42 с.

6. Молоканов В. А. Болезни копытец сельскохозяйственных животных / В. А. Молоканов, Б. С. Семенов, В. С. Камсаев. - Челябинск : ЗАО «Конус», 2003. - $171 \mathrm{c}$.

7. Никулин В. Н. Бактериальный фон при заболеваниях дистального отдела конечностей / В. Н. Никулин // Актуальные проблемы ветеринарной хирургии. - Троицк, 2004. - С. 93.

8. Попов Ю. Г. Значение условно-патогенной микрофлоры при массовых болезнях крупного рогатого скота / Ю. Г. Попов // Актуальные вопросы микробиологии и инфекционной патологи животных: Материалы Междунар. науч.произв. конф. - СПб., 2004. - С. 103-104.

9. Панько I. С. Гнійно-некротичні хвороби пальців у високопродуктивних корів / I. С. Панько, М. В. Петрик // К. : Бібліотека ветеринарної медицини, 2007. $-63 \mathrm{c}$.

10. Фотіна T. I. Вивчення видового спектру мікроорганізмів при гнійно-некротичних ураженнях копитець у великої рогатої худоби / Фотіна Т. I., Улько Л. Г. // Материалы Междунар. наук.практ. конф. - Миколаїв, 2008. - С. 299-303.

11. Фотіна T. I. Значення мікробних асоціацій в патогенезі гнійно-некротичних уражень дистального відділу кінцівок у високопродуктивних корів / Т. І. Фотіна, Л. Г. Улько // Ветеринарна медицина: міжвід. темат. зб. - Х., 2009. Вип. 92. - С. 510-512. 